\title{
Antioxidant and chelating activities from Lion fish (Pterois volitans L.) muscle protein hydrolysates produced by in vitro digestion using pepsin and pancreatin
}

\author{
Luis Chel-Guerrero', David Cua-Aguayo', David Betancur-Ancona', Azucena Chuc-Koyoc', \\ Irma Aranda-González², Santiago Gallegos-Tintoré ${ }^{1 *}$
}

${ }^{1}$ Facultad de Ingeniería Química, Universidad Autónoma de Yucatán, Campus de Ingenierías y Ciencias Exactas, Mérida, Yucatán, México. ${ }^{2}$ Facultad de Medicina, Universidad Autónoma de Yucatán, Avenida Itzáes No. 498 x 59 y 59A Col. Centro C.P. 97000 Mérida, Yucatán, México

\section{A B S T R A C T}

\begin{abstract}
The aim of the present research was to determine the antioxidant, and $\mathrm{Cu}^{2+}$ and $\mathrm{Fe}^{2+}$ chelating activities, amino acid content and estimated molecular weight of proteins and peptides from lion fish muscle-derived hydrolysates obtained by enzymatic hydrolysis with pepsin and pancreatin. The fillets were freeze-dried and hydrolysis was performed, taking aliquots at different times. The degree of hydrolysis, antioxidant activity against $\mathrm{ABTS}^{+}$and $\mathrm{DPPH}, \mathrm{Cu}^{2+}$ and $\mathrm{Fe}^{2+}$ chelating activity, as well as molecular weight estimated by SDS-PAGE and amino acid content by HPLC was determined. The highest degree of hydrolysis (DH) was at 180 min (37.75\%). SDS-PAGE showed proteins with an estimated molecular weight of 45,259 and 42,487 Da, which could be associated with myofibrillar proteins. The progressive degradation of proteins by enzymes was also observed, detecting polypeptides with a EMW of 5,988 and 4,954 Da in the most representative hydrolysates. The $\mathrm{H} 40$ hydrolysate exhibited the highest ABTS and DPPH radical depuration activity, with values of $107.31 \mathrm{mM} / \mathrm{mg}$ protein and $54.27 \%$, respectively. The iron and copper chelating activity was related to $\mathrm{DH}$, since the highest values of iron and copper chelating activity were obtained in hydrolysates $\mathrm{H} 120$ and $\mathrm{H} 140$, with $90.83 \%$ chelation of $\mathrm{Cu}^{2+}$ and $56.33 \%$ chelation of $\mathrm{Fe}^{2+}$, respectively with no significant differences compared to subsequent times. In addition, the antioxidant and chelating activities were possibly related to Trp, Cys, Lys, Pro and Arg content. Lion fish muscle hydrolysates could be a potential source of functional ingredients due to their in vitro antioxidant and chelating activity.
\end{abstract}

Keywords: Antioxidant activity; Chelating activity; Hydolysates; Lion fish; Pepsin-pancreatin

\section{INTRODUCTION}

The lion fish (Pterois volitans L.) is a fish of the Scorpaenidae family and is native to the Eastern Indian and Pacific oceans. Lion fish appeared in the Caribbean, possibly as a result of escape or intentional introduction, apparently from Florida (USA), in the 1980s and since then it spread through the Caribbean ocean (Green et al., 2012). In 2004, it had dispersed in the Bahamas (Whitfield et al., 2007) and by 2008 its sighting was already recorded in the Cayman Islands, Jamaica, the Dominican Republic and the Virgin Islands and Barbados. In 2009 the expansion of this species was already alarming since its territory already included Mexico, Belize, Honduras, Nicaragua, Costa Rica and Panama (Betancur et al., 2011).
Currently, government agencies and ecological conservation organizations are implementing strategies to mitigate the invasion, including sport fishing. In addition, bromatological studies have been carried out, in order to recommend its consumption; in Mexico the National Commission of Natural Protected Areas (CONANP), has put in motion other proposals for its control, promoting the tasting of dishes made with lion fish. On the other hand, marketing and imports of the meat of this fish have been developed, as part of the control strategies.

Current studies agree with the global trend of the search for food that, in addition to its nutritional value, provide benefits to the physiological functions of the body, leading

\footnotetext{
${ }^{*}$ Corresponding author:

Santiago Gallegos-Tintoré, Facultad de Ingeniería Química, Universidad Autónoma de Yucatán, Campus de Ingenierías y Ciencias Exactas, Mérida, Yucatán, México. E-mail: santiago.gallegos@correo.uady.mx
}

Received: 19 July 2019; $\quad$ Accepted: 21 December 2019 
to the formation of a new area of research in the science of food and nutrition related to functional foods. Due to its importance as a nutrient, functional ingredients have become the center of attention of a large number of food scientists and technologists. The use of antioxidants in the food industry generates an interest in research since, oxidant compounds are produced in living organisms degrading proteins, lipids and DNA, decreasing their nutritional and functional value (Dávalos et al., 2004). Antioxidant peptides are those that have the ability to trap free radicals and form complexes with metal ions that catalyze the reactions of these radicals and act by preventing other molecules from binding to oxygen, preventing cell aging and delaying degenerative diseases (Chen et al., 1998)

Chelating peptides are a source of interest, for example in the case of peptides with copper chelating activity are essential to maintain a good antioxidant defense, fighting the oxidative stress of copper by chelating the metal ion (Villarroel et al., 2014). Iron, as well as copper, have the capacity to produce reactive oxygen species that cause the breakdown of the DNA chain and the oxidation of its bases (Burkitt, 2001). They can also be useful in organs such as the brain, where the oxidative process is involved in the development of certain diseases.

Today, fish and other marine sources have gained interest because they are a potential source of antioxidant peptides mainly due to the abundance of raw material from underutilized species or by-products. In addition, several investigations have demonstrated that fish protein hydrolysates as well as their peptides with a specific amino acid sequence exhibit antioxidant, antihypertensive, neuroactive immunomodulatory, antimicrobial, hormonal and mineral regulating, antithrombotic, and anticarcinogenic properties, among others. Also, food-grade microbial enzymes such as alkalase ${ }^{\circledR}$, flavourzyme $\AA$, and protamex $^{\mathrm{TM}}$, from plant sources (such as papain) and animal sources (pepsin and trypsin) have been used to produce antioxidant peptides (Samaranayaka and Li-Chan 2011; Sierra-Lopera et al., 2018).

Several studies have established the relationship between biological activity and molecular weight of peptides, being the fractions with molecular weight between $1-4 \mathrm{kDa}$ of interest for pharmaceutical use (Sierra-Lopera et al., 2018).

Different technologies exist for the isolation and purification of bioactive peptides at the pilot plant level; for instance, by chromatographic methods or the use of membranes, antioxidant peptides have been obtained from the hydrolysis of by-products such as Salmon fins (Salmo sp.), heads of Bluefin leatherjacket (Navodon septentrionalis), skin of Grass carp (Ctenopharyngodonidella), viscera of Squid (Ommastrephes bartrami), muscle of Blue mussel (Mytilus edulis) and Patin (Pangasius sutchi). In addition, calcium chelating peptides have been obtained from scales and bones of Atlantic salmon (Salmo salar L.) and Nile tilapia (Oreochromis niloticus), and dietary supplements obtained from White fish (Brand: Seagest ${ }^{\mathrm{TM}}$ ), Molva (Brand: MOLVAL $\left.{ }^{\circledR}\right)$, Cod (Brand: Norland Hydrolyzed Fish Collagen), sardine (Brand: Valtyron ${ }^{\circledR}$ ) are already marketed in France, the United States and Japan (SierraLopera et al, 2018).

Jensen et al. (2013) has reported that enzymatic hydrolyzates from hake, Hoki, blue mussel and Atlantic salmon have antioxidant capacity. Lin et. al. (2014), reports that Pacific mackerel, spanish mackerel, sablefish and Japanese anchovy, present iron chelating peptides which could be useful as food additives or pharmaceutical agents. It is important to carry out studies that allow know if the Pterois volitans L. from Mexican Caribbean Sea has potential as a raw material for obtaining functional ingredients such as enzymatic hydrolysates. Therefore, the aim of the present research was to determine the antioxidant, and $\mathrm{Cu}^{2+}$ and $\mathrm{Fe}^{2+}$ chelating activities, amino acid content and estimated molecular weight (EMW) of proteins and peptides from lion fish muscle-derived hydrolysates obtained by enzymatic hydrolysis with the commercial enzymes pepsin and pancreatin. The results would allow to extend the use and application of the meat of this fish, giving it an added value and mitigating the invasion.

\section{MATERIALS AND METHODS}

A general description of the methodology can be seen in Fig. 1.

\section{Raw material production}

Red lion fish Pterois volitans L. specimens were collected by divers near Cozumel Island, in the state of Quintana Roo, on the Caribbean coast of Mexico. Fish were gutted and filleted. The skinless fillets freeze-dried in the laboratory until use. The dried sample was pulverized and mixed until it was completely homogeneous. Finally, it was stored in freezing at $-20^{\circ} \mathrm{C}$ in a polyethylene bottle to carry out the tests. Fillet moisture and protein content were analyzed using AOAC methods: moisture (934.01), protein (954.01) (calculated as nitrogen $\mathrm{x} 6.25$ ).

\section{Protein hydrolysate preparation}

A subsample of the freeze-dried fillet was used to obtain the hydrolysates, carrying out two replicates of the process. Protein hydrolysates were isolated from the fillets following the first step of the hydrolysis method described by Megías et al. (2004). Freeze-dried fish fillet/water (5\% w/v) were 

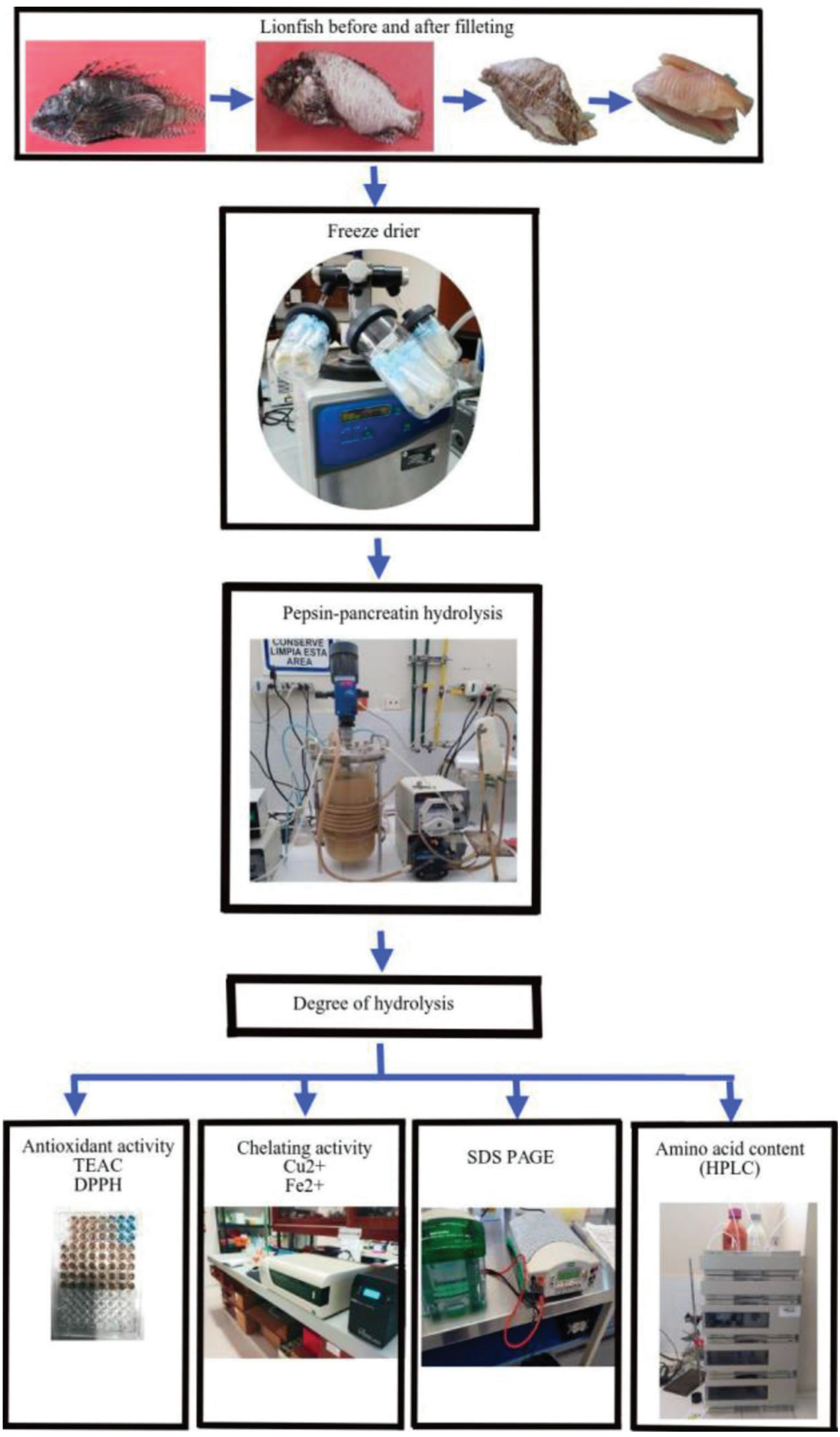

Fig 1. Overview of the methodology. The lionfish's bones, scales and viscera were removed; the fillets were freeze-dried. Hydrolysis was performed with pepsin for 60 minutes and pancreatin for 120 minutes, taking aliquots at different times. The degree of hydrolysis, antioxidant activity against ABTS+ and DPPH, chelating activity of $\mathrm{Cu}^{2+}$ and $\mathrm{Fe}^{2+}$, as well as the molecular weight estimated by SDS-PAGE and amino acid content by HPLC were determined. 
digested at $37^{\circ} \mathrm{C}$ using pepsin (SigmaP7000) at $\mathrm{pH} 2.5$ for 60 minutes, and then with pancreatin (SigmaP1625) at $\mathrm{pH} 7.5$ for 120 minutes. A 1/20 (w/w) enzyme to substrate ratio was used for both enzymes. Aliquots were taken at different times (10, 20, 40, 60 min in case of digestion using pepsin and 80,100,120,160,180 min in case of digestion using pepsin/pancreatin) and hydrolysis was stopped by heat inactivation at $80{ }^{\circ} \mathrm{C}$ for 20 minutes. The resulting hydrolysates (H10, H20, H40, H60, H80, H100, H120, H160, H180) were clarified by centrifugation at $11227 \mathrm{x} g$ for 30 minutes at $5{ }^{\circ} \mathrm{C}$, frozen at $-20^{\circ} \mathrm{C}$ and stored at the same temperature until further use. Hydrolysate protein content was quantified following Lowry et al. (1951) and the result was used in all subsequent analyses.

\section{Degree of hydrolysis}

Degree of hydrolysis (DH) was calculated following Nielsen et al. (2001). The free amino groups were quantified with o-phthalaldehyde (Sigma P0657), in the presence of dithiothreitol, which forms a colored compound detectable at $340 \mathrm{~nm}$ in a spectrophotometer (Thermo Spectronic, Genesys 10UV). The cleaved peptide bonds were quantified using a calibration curve with L-serine (Sigma S4500) as a standard:

\section{Amino acid analysis of the non-hydrolyzed protein} (NHP) and hydrolysates derived from lion fish muscle Amino acid analysis of NHP, H60 and H180 was carried out by acid hydrolysis and HPLC, after derivatization with diethyl ethoxymethylenemalonate (Aldrich D94208), according to the method described by Alaiz et al. (1992), using D,L- $\alpha$ - aminobutyric acid (Aldrich D94208) as internal standard.

\section{Antioxidant and chelating activity of hydrolysates Free radical scavenging activity}

Free radical scavenging activity was measured according to Shimada et al. (1992) with modifications. Protein hydrolysates (1 $\mathrm{mg}$ of protein) were added to DPPH (SigmaD9132) in methanol $(100 \mu \mathrm{L}, 100 \mu \mathrm{M})$ in 96-well plates. Plates were shaken and absorbance at $517 \mathrm{~nm}$ was measured after 30 min using a plate reader. DPPH mixed with $100 \mu \mathrm{L}$ distilled water was used as control. As a standard, $5 \mu \mathrm{g}$ of BHA (from a stock solution of $1 \mathrm{mg}$ of $\mathrm{BHA} / \mathrm{mL}$ ) was used with the same procedure described. Experiments were done in triplicate.

\section{ABTS $^{+}$(2,2'-azino-bis/3-ethylbenzothiazoline-6- sulfonic acid)) decolorisation assay}

Antioxidant activity in the hydrolysates was measured following Pukalskas et al. (2002). The protein hydrolysates of lion fish at a protein concentration of $1 \mathrm{mg} / \mathrm{mL}$ and commercial antioxidant butylated hidroxyanisole (BHA) (Sigma B1253) at the same concentration were analyzed. $\mathrm{ABTS}^{+}$radical cation was produced by reacting ABTS with potassium persulfate. Antioxidant compound content in the hydrolysates was determined by diluting the $\mathrm{ABTS}^{+}$ solution with PBS to an absorbance of $0.800 \pm 0.030 \mathrm{AU}$ at $734 \mathrm{~nm}$. After adding $990 \mu \mathrm{L}$ of diluted ABTS ${ }^{+}$solution (A $734 \mathrm{~nm}=0.800 \pm 0.030)$ to $10 \mu \mathrm{L}$ antioxidant compound or Trolox standard (final concentration 0.5-3.5 mM) in PBS, absorbance was read at ambient temperature exactly $6 \mathrm{~min}$ after initial mixing. Experiments were done in triplicate.

\section{Copper chelating activity}

Copper $\left(\mathrm{Cu}^{2+}\right)$-chelating activity was determined using the pyrocatechol violet reagent, according to Saiga et al. (2003). Protein hydrolysates (equivalent to $1 \mathrm{mg}$ protein) were added to Eppendorf tubes containing $1 \mathrm{~mL} 50 \mathrm{mM}$ sodium acetate buffer ( $\mathrm{pH}$ 6.0), $25 \mu \mathrm{L}$ $4 \mathrm{mM}$ pyrocatechol violet (Sigma P7884), and $10 \mu \mathrm{g} \mathrm{Cu}$ $\left(\mathrm{CuSO}_{4}\right)$. Ethylenediaminetetraacetic acid (EDTA) $(50 \mu \mathrm{g})$ was used as a positive control. Absorbance at $632 \mathrm{~nm}$ was measured after incubation for $1 \mathrm{~min}$ at room temperature. Experiments were done in triplicate.

\section{Iron chelating activity}

Iron $\left(\mathrm{Fe}^{2+}\right)$ chelating activity was measured based on formation of the $\mathrm{Fe}^{2+}$-ferrozine complex, according to Carter (1971). Protein hydrolysates (equivalent to $1 \mathrm{mg}$ protein) were added to Eppendorf tubes containing $1 \mathrm{~mL} 100 \mathrm{mM}$ sodium acetate buffer ( $\mathrm{pH} 4.9)$ and $100 \mu \mathrm{L} \mathrm{FeCl}_{2} \cdot 4 \mathrm{H}_{2} \mathrm{O}$ solution $(0.01 \mathrm{mg} \mathrm{Fe} / \mathrm{mL}$ water). Again, EDTA (50 $\mu \mathrm{g}$ ) was used as a positive control. Absorbance at $562 \mathrm{~nm}$ was measured after adding the ferrozine solution $(50 \mu \mathrm{L}, 40 \mathrm{mM}$ in water) (Sigma P5338) and incubating for $30 \mathrm{~min}$ at room temperature. Experiments were done in triplicate.

\section{Sodium dodecyl sulfate-polyacrylamide gel electrophoresis (SDS-PAGE)}

This analysis was done following Schägger and Jagow (1987), through 18\% acrylamide gel and a 4\% stacking gel. Peptide fractions $(5-6 \mu \mathrm{g} / \mu \mathrm{L}$ of protein) were dissolved separately in a sample buffer and heated to $100{ }^{\circ} \mathrm{C}$ for $5 \mathrm{~min}$. Runs were done at $40 \mathrm{~mA}$ for $1.5 \mathrm{~h}$ in a Miniprotean electrophoresis chamber (BIORAD, Hercules, California). Wells were loaded with $10 \mu \mathrm{g}$ of the protein or one of the hydrolysates; a kaleidoscope polypeptide standard (BIORAD, USA, Cat. \#1610325) was used which contained carbonic anhydrase $(31.5 \mathrm{kDa})$; soy trypsin inhibitor $(22.9 \mathrm{kDa})$; lysozyme $(14.1 \mathrm{kDa})$, aprotinin $(7.9 \mathrm{kDa})$ and insulin $(3.2 \mathrm{kDa})$.

\section{Statistical analysis}

A one-way analysis of variance (ANOVA) with a 5\% significance level was applied to the results using the Statgraphics Centurion XV program. The Duncan method was used to compare the means between hydrolysates $\mathrm{DH}$ values and in vitro activities. 


\section{RESULTS AND DISCUSSION}

\section{Moisture and protein determination}

The lion fish freeze-dried fillet had 81.64 $\pm 0.12 \%$ (d.b) of protein and $11.46 \pm 0.1 \%$ of moisture, similar to the $88.6 \pm 0.3 \%$ and $3.6 \pm 1.9 \%$, respectively reported in northern Pacific hake (Merluccius) by Pacheco et al. (2008). According to Clemente et al. (1999) the lyophilized fillet could be considered as a protein concentrate since it has a percentage higher than $65 \%$.

\section{Degree of hydrolysis (DH)}

The degree of hydrolysis ranged from $3.13 \pm 2.34 \%$ to $37.74 \pm 0.38 \%$, as seen in the hydrolysis kinetics (Fig. 2). This could be due to lysosomal proteases within in the fish muscle, which contribute to the proteolytic breakdown (Samaranayaka et al., 2011). Fang et al. (2012) reported a $\mathrm{DH}$ of $5.30 \pm 0.3 \%$ in tilapia (Oreochromis niloticus) similar to that obtained in this study.

Characteristic hydrolysis kinetics is observed with the pepsin-pancreatin system. During the first stage, when pepsin is added, digestion begins, obtaining the highest $\mathrm{DH}$ at $60 \mathrm{~min}(19.19 \pm 2.2 \%)$. This may be due to that marine-derived proteins are more digestible than plantderived proteins, and even some others from animals (He et al., 2013). In the second stage of digestion, the presence of pancreatin again leads to a considerable increase of $\mathrm{DH}$ with respect to time, since at $80 \mathrm{~min}$ the $\mathrm{DH}$ was $31.86 \pm 0.39 \%$ (Fig. 2), which could be attributed to the increased number of available substrates generated by previous digestion with pepsin (Montoya et al., 2008).

In $\mathrm{H} 100$ the $\mathrm{DH}$ was $32.33 \pm 4.42 \%$, without statistical difference with respect to H80 ( $p>0.05)$, similar to what was found between $\mathrm{H} 140$ and H160, which had 35.33 $\pm 0.41 \%$ and $35.46 \pm 0.74 \%$ of $\mathrm{DH}$, respectively and without statistical differences $(\mathrm{p}>0.05)$.

This performance may also be due to the depletion of substrate during the digestion process, resulting in $\mathrm{DH}$ with no apparent difference (Eisenthal-Danson et al., 2002). You et al. (2010) report a DH higher than that obtained in the present work, with a DH of $46.6 \pm 0.3 \%$ in Dojo fish hydrolysates (Misgurnus anguillicaudatus) in conditions similar to those used in this work. Molla et al. (2011) reported a $\mathrm{DH}$ of $30 \%$ in the hydrolysate of the visceral protein of beluga (Huso huso) digested with the Protamex $\AA$ enzyme, similar to that obtained in this study.

\section{Electrophoretic profile}

Electrophoretic analysis (Fig. 3) of the fillet (NHP) and protein hydrolysates (H20, H60, H80, H120 and H180 min) of Pterois volitans L. showed the presence of three majority bands (marked with arrows). The molecular weight of the band with the highest molecular weight could not be determined, however, the second and third bands had an estimated molecular weight of 45,259 and 42,487Da which could be associated to myofibrillary proteins (paramyosin), the second to tropomyosin and the third to actin, as reported by Sánchez-Sanchez et al. (2013). Benjakul et al. (1997) reported the presence of bands with weights similar to those found here, in Pacific hake (Merluccius gayi), with a weight between 112-82 $\mathrm{KDa}$ and $45 \mathrm{KDa}$, which are attributed to endogenous enzymes. Proteins were also detected in NHP with estimated molecular weights of 27,297, 24,055, 20,539, 19,281, 14,057, and 9,321Da.

A progressive degradation of proteins was also observed as polypeptides with an estimated molecular weight of

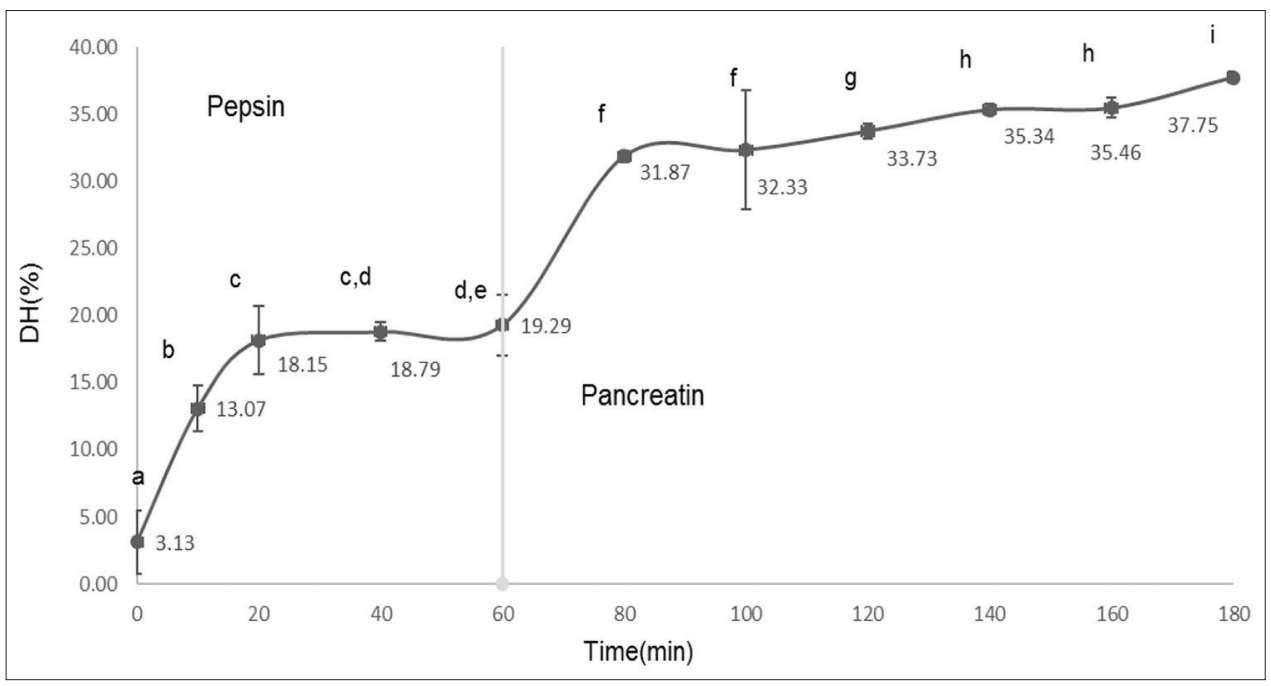

Fig 2. Hydrolysis degree kinetics of lion fish muscle protein treated with pepsin and pancreatin. Error bars indicate the standard deviation. Statistically significant differences are indicated by different letters $(p<0.05)$. 
5,988 and 4,954Da were found. Furthermore, a greater degradation is observed in H180, which remains unchanged

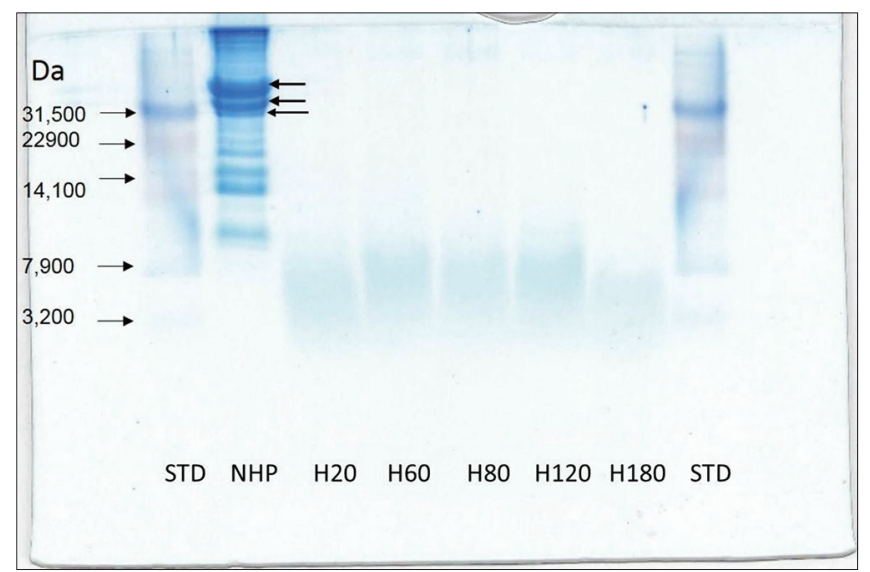

Fig 3. Electrophoretic profile of NHP and hydrolysates derived from lion fish muscle subjected to enzymatic hydrolysis with pepsin and pancreatin. until the end of digestion, since the greater the DH, the more likely it is to obtain smaller peptides. When assessing the behavior of the hydrolysates, it is observed a trend towards a decrease in the size of the proteins in comparison with the profile of the non-hydrolysed protein, therefore a better solubility and presence of bioactive peptides are expected (Sánchez-Sanchez et al., 2014).

\section{Antioxidant and chelating activity of protein hydrolysates derived from $\mathbf{P}$. volitans $\mathbf{L}$.}

Determination of DPPH radical scavenging activity

Fig. 4A shows the DPPH free radical scavenging activity of lion fish muscle protein hydrolysates.

NHP had a DPPH free radical uptake capacity of $19.86 \pm 0.26 \%$, given by the degree of hydrolysis (Thiansilakul et. al., 2007). When the commercial enzyme pepsin was added, there was an increase in antioxidant activity, from $45.32 \pm 0.41 \%$ to $54.27 \pm 0.53 \%$, finding the

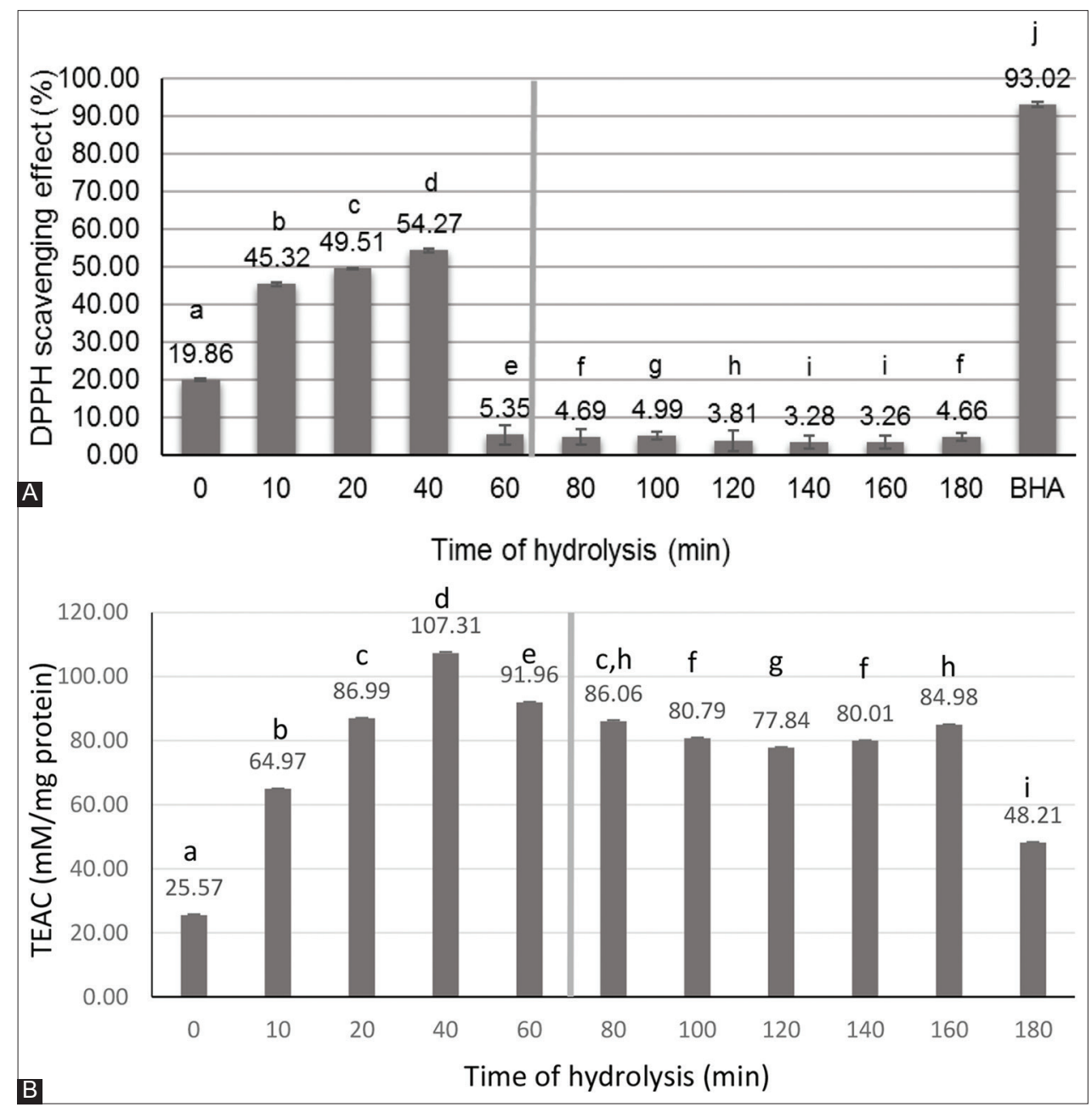

Fig 4. (A-B). Percentage of DPPH radical scavenging activity of fillet ( $0 \mathrm{~min}$ ) and hydrolysates (1 mg protein) derived from lion fish muscle subjected to enzymatic hydrolysis with pepsin and pancreatin. Error bars indicate the standard deviation. Different letters indicate statistical difference $(p<0.05)$. Standard $5 \mu \mathrm{g}$ of BHA. Antioxidant activity (TEAC values) of NHP and hydrolysates $(1 \mathrm{mg}$ protein) derived from lion fish muscle subjected to enzymatic hydrolysis with pepsin and pancreatin. Error bars indicate the standard deviation. Different letters indicate statistical difference $(p<0.05)$. Standard BHA $(1 \mathrm{mg} / \mathrm{mL})$. 
highest activity in $40 \mathrm{~min}$, however an important decrease is observed at 60 minutes $(5.35 \pm 2.59 \%)$. The addition of pancreatin at 80 minutes did not increase antioxidant activity and this behavior continued in subsequent minutes. The BHA standard had $93.02 \pm 0.75 \%$ of DPPH free radical uptake capacity.

Nakajima et al. (2008) which evaluated the antioxidant capacity of Atlantic salmon (Salmo salar), Coho salmon (Onchorhynchus Kisutch) and Alaska pollack (Theragra chalcogramma), which underwent similar sequential hydrolysis with pepsin (2 h)/pancreatin (3h), reported that the antioxidant capacity ranged from 20 to $30 \%$ during pepsin digestion, and significantly falls to approximately $5 \%$, which is similar to the pattern found here. Changes in the size and composition of peptides, as well as the presence of free amino acids, generated during hydrolysis, affect antioxidant capacity (Klompong et al., 2007). This may explain the decrease in antioxidant capacity from 60 minutes.

In the amino acid profile (Table 1), it is observed the highquality of the proteins of the freeze-dried lion fish fillet. A higher content of essential amino acids, such as His, Thr, Val, Ile, Leu, Phe, Lys and Trp, was found compared to the intake recommended by FAO (2007) for adults, except for Cys with a lower content. Morales et al. (2016) noted that low levels of Cys and Trp are usually found in fish proteins. It has also been reported that antioxidant activity is due to the presence of amino acids and peptides containing residues of Val, Leu, Ile, Ala, Phe, Cys or Lys in N-terminal. However, the presence of these amino acids in the hydrolysates H60 and H180 does not explain the behavior regarding the abrupt decrease in the activity detected in the hydrolysate obtained with pepsin (H60) and pepsin-pancreatin in the longest time (H180) (Table 1).

\section{Determination of ABTS + radical uptake activity}

The trolox antioxidant equivalent coefficient (TEAC) is shown in Fig. 4B. The fillet of lyophilized lion fish (NHP) had a $25.57 \pm 0.26$ of TEAC.

TEAC ( $\mathrm{mM} / \mathrm{mg}$ protein) increased gradually with the hydrolysates derived from pepsin digestion at minutes 10 to 40 (64.97 to 107.31); at 60 minutes, it had a slight decrease (91.96) that remained stable during pancreatin digestion and up to 160 minutes. A decrease in TEAC (48.21) was observed at 180 minutes after pancreatin digestion. The TEAC value of the antioxidant BHA was $373.49 \mathrm{mM} / \mathrm{mg}$ of protein.

It is worth noting that, even though the protein hydrolysate $\mathrm{H} 180$ had the highest $\mathrm{DH}(37.75 \pm 0.38 \%)$, the uptake value of the radical $\mathrm{ABTS}^{+}$was the lowest among the other hydrolysate. This performance was also observed in protein hydrolysates of ornate threadfin bream muscle (Nemipterus bexodon), generated with pepsin from Skipjack tuna stomach (Katsuwonus pelamis) (Nalinanon et al., 2011), where a TEAC of $150 \mathrm{mM} / \mathrm{mg}, 159 \mathrm{mM} / \mathrm{mg}$ and $151 \mathrm{mM} / \mathrm{mg}$ was reported in hydrolysates with DH of $10 \%, 20 \%$ and $30 \%$, respectively. Zheng et al., (2016) reported that the amino acids Tyr, Trp, Cys, Met, Lys and Phe capure the radical $\mathrm{ABTS}^{+}$, however the capacity decreases in the following order: $\operatorname{Tyr}>\operatorname{Trp}>$ Cys, while the amino acids Met, Lys and Phe display a lower uptake of this radical. Therefore, as shown by the amino acid content in Table 1 , the highest concentration of Tyr, Cys, Lys and Trp in H60 compared to H180, could be promoting the uptake activity of the radical ABTS ${ }^{+}$. These results suggest that lion fish protein hydrolysates contain amino acids or peptides that are electron donors which can react with free radicals to convert them into stable products and stop the pro-oxidant chain reaction (Nalinanon et al., 2011).

\section{$\mathrm{Cu}^{2+}$ chelating activity}

NHP showed a chelating activity of $45.31 \pm 0.98 \%$, while protein hydrolysates exhibited a higher activity (Fig. 5A). The chelating capacity of $\mathrm{Cu}^{2+}$ during pepsin hydrolysis increased over time; however, the addition of pancreatin increased this activity and also raised over time, reaching a maximum value at 120 minutes. This may be due to the

\begin{tabular}{|c|c|c|c|c|}
\hline $\begin{array}{l}\text { Amino } \\
\text { Acids }\end{array}$ & $\begin{array}{l}\text { Lion fish } \\
\text { muscle } \\
\text { (NHP) }\end{array}$ & $\begin{array}{c}\text { Pepsin } \\
\text { H60 }\end{array}$ & $\begin{array}{c}\text { Pepsin- } \\
\text { pancreatin } \\
\text { H180 }\end{array}$ & $\begin{array}{c}\text { FAO } \\
(2007)\end{array}$ \\
\hline$A s x^{1}$ & $9.95 \pm 0.002$ & $7.29 \pm 0.08$ & $7.89 \pm 0.25$ & \\
\hline $\mathrm{Gl} \mathrm{x}^{2}$ & $15.35 \pm 0.56$ & $12.25 \pm 0.78$ & $11.84 \pm 1.36$ & \\
\hline Ser & $2.8 \pm 0.08$ & $2.02 \pm 0.24$ & $1.85 \pm 0.29$ & \\
\hline His & $1.75 \pm 0.09$ & $1.52 \pm 0.03$ & $1.66 \pm 0.10$ & 1.5 \\
\hline Gly & $4.37 \pm 0.40$ & $4.77 \pm 0.09$ & $4.53 \pm 0.42$ & \\
\hline Thr & $3.93 \pm 0.01$ & $3.81 \pm 0.03$ & $3.80 \pm 0.06$ & 2.3 \\
\hline Arg & $10.96 \pm 0.36$ & $12.53 \pm 0.18$ & $13.10 \pm 0.09$ & \\
\hline Ala & $2.92 \pm 0.04$ & $2.81 \pm 0.03$ & $2.89 \pm 0.17$ & \\
\hline Pro & $6.47 \pm 0.55$ & $5.29 \pm 0.06$ & $7.83 \pm 3.17$ & \\
\hline Tyr & $2.68 \pm 0.07$ & $2.29 \pm 0.12$ & $2.14 \pm 0.33$ & \\
\hline Val & $10.82 \pm 0.38$ & $13.37 \pm 0.17$ & $13.13 \pm 0.38$ & 3.9 \\
\hline Met & $2.58 \pm 0.04$ & $1.89 \pm 0.08$ & $2.21 \pm 0.17$ & 1.6 \\
\hline Cys & $0.13 \pm 0.01$ & $1.30 \pm 0.70$ & $0.03 \pm 0.01$ & $2.2^{\mathrm{d}}$ \\
\hline lle & $4.46 \pm 0.06$ & $4.19 \pm 0.09$ & $4.36 \pm 0.07$ & 3.0 \\
\hline Leu & $8.01 \pm 0.12$ & $8.22 \pm 0.20$ & $8.12 \pm 0.18$ & 5.9 \\
\hline Phe & $3.62 \pm 0.02$ & $3.29 \pm 0.01$ & $3.47 \pm 0.18$ & $3.0^{c}$ \\
\hline Lys & $9.20 \pm 0.09$ & $9.30 \pm 0.40$ & $8.83 \pm 0.56$ & 4.5 \\
\hline Trp & 2.63 & $3.84 \pm 0.26$ & $2.30 \pm 0.92$ & 0.6 \\
\hline Hydrophobic & & 42.91 & 44.31 & \\
\hline Neutral & & 14.20 & 12.36 & \\
\hline Hydrophilic & & 42.89 & 43.33 & \\
\hline
\end{tabular}

Hydrophobic amino acids: Ala, Val, Met, Phe, Leu, Ile, Pro, Trp. Neutral Amino Acids: Ser, Gly, Thr, Tyr, Cys; ${ }^{C} P h e+$ Tyr. ${ }^{d}$ Met + Cys ${ }^{1}$ Asx: Asp+Asn; ${ }^{2} \mathrm{Glx}$ : Glu+Gln 


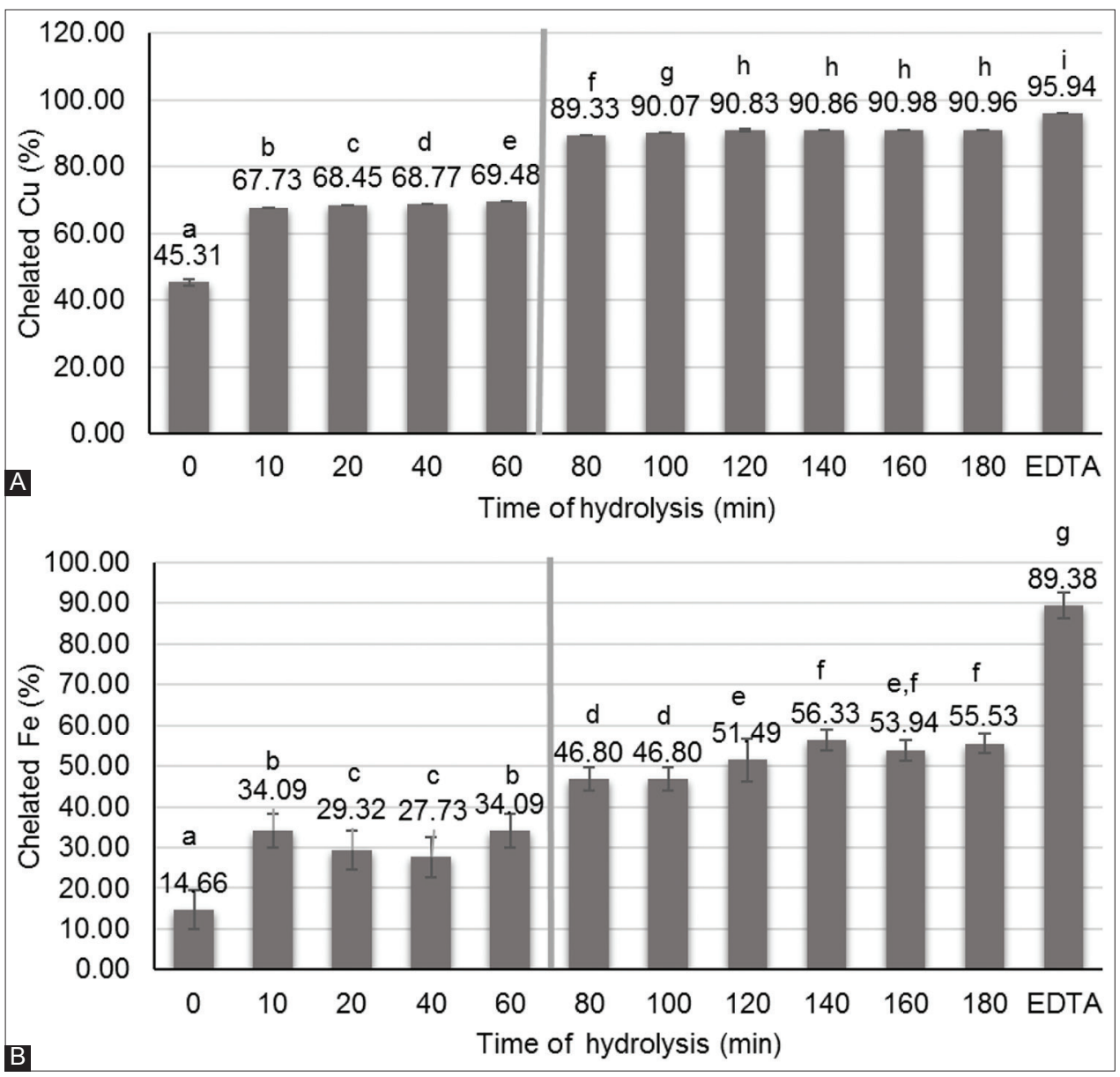

Fig 5. (A-B) Copper chelating activity of NHP and hydrolysates (1 mg protein) derived from lion fish muscle subjected to enzymatic hydrolysis with pepsin and pancreatin. Error bars indicate the standard deviation. Different letters indicate statistical difference $(p<0.05)$. Standard $5 \mu \mathrm{g}$ of EDTA. Iron chelating activity of NHP and hydrolysates (1 mg protein) derived from lion fish muscle subjected to enzymatic hydrolysis with pepsin and pancreatin. Error bars indicate the standard deviation. Different letters indicate statistical difference $(p<0.05)$. Standard $50 \mu g$ of EDTA.

process of hydrolysis, as the protein structure changes over time to promote chelating activity (Eisenthal-Danson et al., 2002).

The $\mathrm{Cu}^{2+}$ chelating activity observed are higher than that reported by Zhuang et al., 2010 in jellyfish (Rhopilema esculentum) digested with a mixture Properasa E and trypsin (1 $\mathrm{mg}$ of protein evaluated), which had an activity of $40 \%$. Conversely, Guo (2015) reported lower values $(23.22 \pm 3.35 \%)$ in the Alaska Pollok fish (Gadus chalcogrammus) digested with trypsin $\left(50^{\circ} \mathrm{C}, \mathrm{pH} 8,4 \mathrm{~h}\right)$.

Estrella (2017) reported the presence of His in lion fish, which is an amino acid characterized by being a copper chelator, whereas Ghanbari et al. (2015) reported that the high chelating capacity of copper is associated to the presence of glutamic acid and aspartic, as well as basic amino acids such as Lys and Arg. As seen in table 1, NHP had a His content ( $\mathrm{g} / 100 \mathrm{~g}$ of protein) of 1.75 , while $\mathrm{H} 60$ was 1.52, and H180 was 1.66. The Lys content in NHP was similar to that found in H60, while H180 was slightly lower.
However, with respect to $\mathrm{Arg}$ (g/100 g of protein), H180 had the highest content (13.10), followed by H60 (12.53) and NHP (10.96). Therefore, it is possible that Arginine is the main amino acid that explain the differences observed. The activity of chelating peptides can prevent the oxidative activity of copper through the chelation of this metallic ion, so it could prevent the oxidative activity that occurs in the stomach, as well as to inhibit the oxidation of lowdensity lipoproteins induced by copper in the bloodstream (Burkitt, et al., 2001), and contribute to in the treatment of Wilson's disease, in which the liver is unable to eliminate copper properly (Jiménez et al., 2010).

\section{$\mathrm{Fe}^{2+}$ chelating activity}

NHP had $14.66 \pm 4.68 \%$ of iron chelation activity, and as shown in Fig. 5B, this activity increased in relation to time and degree of hydrolysis. The iron chelating capacity was increased when pancreatin was added, with the highest peak at 140 minutes. Girgih et al. (2013) reported iron chelation values about $30 \%$ on the fillet of salmon (Salmo salar) hydrolyzed with pepsin. However, Sila et al. (2014) 
reported values higher than $80 \%$ in a digestion system with Alcalase ${ }^{\circledR}$ using shrimp (P. longirostris) as substrate. Klompong et al. (2007) analyzed the fish protein Selaroides leptolepis subjected to hydrolysis with Alcalase ${ }^{\circledR}$ and reported chelation values greater than $60 \%$, similar to the highest iron chelation values reported in this work. The chelating activity of metals can be associated to the structure, molecular weight and composition of amino acids, being Gly and His, the amino acids that have been reported to have the highest iron chelating activity (Lin et al., 2014). Estrella (2017) found these amino acids in lion fish protein as well as protein hydrolysates obtained by treatment with alcalase ${ }^{\circledR}$. However, chelating activity may also account for the presence of the amino acids Pro and Arg (Table 1). The importance of peptides with iron chelating capacity is that they can be used as antioxidants or for the treatment of diseases such as thalassemia or myelodysplastic syndrome, which are a class of anemia characterized by impaired hemoglobin production which is treated with constant blood transfusions, leading to accumulation of mitochondrial iron (Villegas, 2006). As it can be observed, the chelating activity of iron is less compared to that of copper, which is explained by the fact that iron has a greater number of coordination sites and therefore more peptides are required to chelate it in a greater proportion (Ruiz, 2009).

\section{CONCLUSIONS}

Lion fish (Pterois volitans L.) muscle hydrolysates were obtained using a pepsin-pancreatin sequential system, where the highest DH was $37.74 \pm 0.33 \%$ at $180 \mathrm{~min}$ of digestion. The enzymatic digestion generated peptides with an estimated molecular weight between 4,954 and $5,988 \mathrm{Da}$, which were not detected in the electrophoretic profile of the muscle. The highest antioxidant activity for both $\mathrm{DPPH}$ and $\mathrm{ABTS}^{+}$was found with pepsin digestion at minute 40, while the chelating activity of $\mathrm{Cu}^{2+}$ and $\mathrm{Fe}^{2+}$ was higher in the pepsin-pancreatin system at minute 120 and 140, respectively. Higher Trp, Cys and Lys content in pepsin hydrolysates at $60 \mathrm{~min}$ may be associated with higher antioxidant activity against $\mathrm{ABTS}^{+}$, while higher Pro and Arg content in pepsin-pancreatin hydrolysates at 180 min may be associated with higher $\mathrm{Cu}^{2+}$ and $\mathrm{Fe}^{2+}$ chelating activity. Therefore, hydrolysates obtained from lion fish high-quality muscle protein are a potential source of ingredients with antioxidant and chelating activity, which in the future could be used as functional ingredients.

\section{ACKNOWLEDGEMENT}

The authors would like to acknowledge to the "Programa para el Mejoramiento del Profesorado" for the support received for the development of the project PROMEP/103.5/13/6979.

\section{Authors ' contributions}

Luis Chel-Guerrero participated in the design of the research, acquisition and analysis of data, involved in drafting the paper for important intellectual content. David Cua-Aguayo and Azucena Chuc-Koyoc participated in the adaptation of some analytical techniques, acquisition and analysis of data. David Betancur-Ancona, participated in the analysis of data, involved in revising the paper critically. Irma Aranda-González participated in the acquisition and data analysis, involved in revising the paper critically. Translate the manuscript from Spanish to English. Santiago Gallegos-Tintore participated in the design of the research (head of research project), acquisition and analysis of data, involved in drafting the paper for important intellectual content and revising the paper critically. Translate the manuscript from Spanish to English. All authors read and approved the manuscript.

\section{Conflict of interest}

The authors declare no conflict of interest.

\section{REFERENCES}

AOAC. 1997. Official Methods of Analysis, Association of Official Analytical Chemists, Washington, DC, pp. 2-32.

Betancur, R., A. Hines, A. Acero, G. Ortí, A. E. Wilbur and D. W. Freshwater. 2011. Reconstructing the lion fish invasion: Insights into Greater Caribbean biogeography. J. Biogeogr. 38: 1281-1293.

Benjakul, S. and M. T. Morrissey. 1997. Protein hydrolysates from Pacific whiting solid wastes. J. Agric. Food Chem. 45: 34233430.

Burkitt, M. J. 2001. A critical overview of the chemistry of copperdependent low density lipoprotein oxidation: Roles of lipid hydroperoxides, a-tocopherol, thiols, and ceruloplasmin. Arch. Biochem. Biophys. 394: 117-135.

Carter, P. 1971. Spectrophotometric determination of serum iron at the submicrogram level with a new reagement (ferrozine). Anal. Biochem. 40: 455-458.

Chen, H. M., K. Muramoto, F. Yamauchi, K. Fujimoto and K. Nokihara. 1998. Antioxidative properties of histidine-containing peptides designed from peptide fragments found in the digests of a soybean protein. J. Agric. Food Chem. 46: 49-53.

Clemente, A., J. Vioque and F. Millán. 1999. Hidrolizados proteicos de origen vegetal. Grasas Aceites. 2: 289-296.

Dávalos, A., M. Miguel, B. Bartolomé and R. López-Fandiño. 2004. Antioxidant activity of peptides derived from egg white proteins by enzymatic hydrolisis. J. Food Prot. 67: 1939-1944.

Eisenthal, R. and M. Danson. 2002. Enzyme Assays. Oxford University Press, New York, pp. 79-100.

Estrella, Y. 2017. Biofuncionalidad de fracciones peptídicas obtenidas de hidrolizados proteicos de músculo del pez león (Pterois volitans L.). (bachelor dissertation), Autonomous University of Yucatan, Mexico.

Fang, J., J. He, Y. Zhuang and L. Sun. 2012. Purification and identification of antioxidant peptides from enzymatic hydrolysates of tilapia (Oreochromis niloticus) frame protein. Molecules. 17: 12836-12850. 
FAO/WHO. 2007. Protein and Amino Acid Requirements in Human Nutrition. Report of Joint WHO/FAO/UNU Expert Consultation. Food and Nutrition. WHO Technical Report Series 935, Food Agriculture Organizations and the World Health Organization, Geneva, pp.148-152.

Ghanbari, R., M. Zarei, A. Ebrahimpour, A. Abdul-Hamid, A. Ismail and N. Saari. 2015. Angiotensin-I converting enzyme (ACE) inhibitory and antioxidant activities of sea cucumber (actinopyga lecanora) hydrolysates. Int. J. Mol. Sci. 16: 28870-28885.

Girgih, A. T., C. C. Udenigwe, F. M. Hasan, T. A. Gill and R. E. Aluko. 2013. Antioxidant properties of salmon (Salmo salar) protein hydrolysate and peptide fractions isolated by reverse-phase HPLC. Food Res. Int. 52: 315-322.

Green, S. J., J. L. Akins and J. A. Morris. 2012. Lionfish Dissection: Techniques and Applications. NOAA Technical Memorandum NOS NCCOS 139, United States, p. 1.

Guo, L., P. A. Harnedy, L. Zhang, B. Li, Z. Zhang, H. Hou, X. Zhao and R. J. Fitzgerald. 2015. In vitro assessment of the multifunctional bioactive potential of Alaska pollock skin collagen following simulated gastrointestinal digestion. J. Sci. Food Agric. 95: 1514-1520.

He, S., C. Franco and W. Zhang. 2013. Functions, applications and production of protein hydrolysates from fish processing coproducts (FPCP). Food Res. Int. 50: 289-297.

Jensen I. J., K. E Eilertsen, H. K. Mæhre, E. O. Elvevoll and R. Larsen. 2013. Health effects of antioxidative and antihypertensive peptides from marine resources. In: K. Se-Kwon (Ed.), Marine Protein and Peptides, John Wiley \& Sons, Ltd, Breivika, Norway, pp. 297-317.

Jiménez, A. M. and M. Ruiz-Moreno. 2010. Enfermedad de Wilson. In: Protocolos Diagnóstico-Terapéuticos de Gastroenterología, Hepatología y Nutrición Pediátrica, SEGHNP-AEP, Ergon, Madrid, pp. 189-197.

Klompong, V., S. Benjakul, D. Kantachote, F. Shahidi. 2007. Antioxidative activity and functional properties of protein hydrolysate of yellow stripe trevally (Selaroides leptolepis) as influenced by the degree of hydrolysis and enzyme type. Food Chem. 102: 1317-1327.

Lin, H. M., S. G. Deng and S. B. Huang. 2014. Antioxidant activities of ferrous-chelating peptides isolated from five types of low-value fish protein hydrolysates. J. Food Biochem. 38: 627-633.

Lowry, O., N. J. Rosebrough, A. L. Farr and R. J. Randall. 1951. Protein measurement with the Folin phenol reagent. J. Biol. Chem. 193: 265-275.

Megías, C., M. Yust, J. Pedroche, H. Lquari, J. Girón-Calle, M. Alaiz, F. Millán and J. Vioque. 2004. Purification of an ACE inhibitory peptide after hydrolysis of sunflower (Helianthus annuus L.) protein isolates. J. Agr. Food Chem. 52: 1928-1932.

Molla, A. E. and H. G. Hovannisyan. 2011. Optimization of enzymatic hydrolysis of visceral waste proteins of beluga Huso huso using protamex. Int. Aquat. Res. 3: 93-99.

Montoya, C. A., A. S. Gomez, J. P. Lallès, W. B. Souffrant, S. Beebe and P. Leterme. 2008. In vitro and in vivo protein hydrolysis of beans (Phaseolus vulgaris) genetically modified to express different phaseolin types. Food Chem. 106: 1225-1233.

Morales-Medina, R., F. Tamm, A. M. Guadix, E. M. Guadix and S. Drusch. 2016. Functional and antioxidant properties of hydrolysates of sardine ( $S$. pilchardus) and horse mackerel (T. mediterraneus) for the microencapsulation of fish oil by spray-drying. Food Chem. 194: 1208-1216.

Nakajima, K., Y. Yoshie-Stark and M. Ogushi. 2009. Comparison of ACE inhibitory and DPPH radical scavenging activities of fish muscle hydrolysates. Food Chem. 114: 844-851.
Nalinanon, S., S. Benjakul, H. Kishimura, F. Shahidi. 2011. Functionalities and antioxidant properties of protein hydrolysates from the muscle of ornate threadfin bream treated with pepsin from skipjack tuna. Food Chem. 124: 1354-1362.

Nielsen, P. M., D. Petersen and C. Dambmann. 2001. Improved method for determining food protein degree of hydrolysis. J. Food Sci. 66: 642-646.

Pacheco-Aguilar, R., M. A. Mazorra-Manzano and J. C. Ramírez Suárez. 2008. Functional properties of fish protein hydrolysates from Pacific whiting (Merluccius productus) muscle produced by a commercial protease. Food Chem. 109: 782-789.

Pukalskas, A., T. Van Beek, R. P. Venskutonis, J. P. Linssen, A. Van Veldhuizen and A. de Groot. 2002. Identification of radical scavengers in sweet grass (Hierochloe odorata). J. Agr. Food Chem. 50: 2914-2919.

Ruiz, R. B. 2009. Propiedades Antioxidantes de los Productos de la Reacción de Maillard y su Influencia en la Absorción de Hierro y Cobre. Relación Con la Capacidad Quelante de Metales (Doctoral dissertation), University of Granada, Granada.

Samaranayaka, A. G. P. and E. C. Y. Li-Chan. 2011. Food-derived peptidic antioxidants: A review of their production, assessment, and potential applications. J. Funct. Foods. 3: 229-254.

Saiga, A., S. Tanabe and T. Nishimura. 2003. Antioxidant activity of peptides obtained from porcine myofibrillar proteins by protease treatment. J. Agr. Food Chem. 51: 3661-3667.

Sánchez-Sanchez, A., J. L. Arías-Moscoso, W. Torres-Arreola, E. Marquez-Rios, J. L. Cárdenas-López, G. García-Sánchez and J. M. Ezquerra-Brauer. 2014. Caracterización de hidrolizados de desechos de calamar gigante (Dosidicus gigas) obtenidos por autohidrólisis y un proceso químico-enzimático. CyTA-J Food. 12: 85-96.

Schägger, H. and G. Von Jagow. 1987. Tricine-sodium dodecyl sulfate-polyacrylamide gel electrophoresis for the separation of proteins in the range from 1 to $100 \mathrm{kDa}$. Anal. Biochem. 166: 368-379.

Sierra-Lopera, L. M., C. T. Sepúlveda-Rincón, P. Vásquez Mazo, O. A. Figueroa-Moreno and J. E. Zapata-Montoya. 2018 By products of aquaculture processes: Development and prospective uses. Rev. Vitae. 25: 128-140.

Shimada, K., K. Fujikawa, K. Yahara and T. Nakamura. 1992. Antioxidative properties of xanthan on the autoxidation of soybean oil in cyclodextrin emulsion. J. Agric. Food Chem. 40: 945-948.

Sila A., N. Sayari, R. Balti, O. Martinez-Alvarez, N. Nedjar-Arroume, N. Moncef and A. Bougatef. 2014. Biochemical and antioxidant properties of peptidic fraction of carotenoproteins generated from shrimp by-products by enzymatic hydrolysis. Food Chem. 148: $445-452$.

Thiansilakul, Y., S. Benjakul and F. Shahidi. 2007. Antioxidative activity of protein hydrolysate from round scad muscle using alcalase and flavourzyme. J. Food Biochem. 31: 266-287.

Villarroel, J., D. Paredes, O. M. Alarcón-Corredor, A. Villarroel, R. Alfonzo, Y. Hidalgo, C. Paredes and Y. Paredes. 2014. Efecto del cobre sobre el contenido sérico de albúmina y de lípidos y sobre las concentraciones séricas y tisulares de cobre en ratas con síndrome nefrótico experimental. Medula. 23: 33-38.

Villegas, A. 2006. Nuevas perspectivas terapéuticas en la sobrecarga de hierro. An. Med. Intern. 23: 511-512.

Whitfield, P. E, J. A. Hare, A. W. David, S. L. Harter, R. C. Muñoz and C. M. Addison. 2007. Abundance estimates of the indo-pacific lion fish Pterois volitans/miles complex in the Western North Atlantic. Biol. Invasions. 9: 53-64. 
You, L., M. Zhao, J. M. Regenstein and J. Ren. 2010. Changes in the antioxidant activity of loach (Misgurnus anguillicaudatus) protein hydrolysates during a simulated gastrointestinal digestion. Food Chem. 120: 810-816.

Zhuang, Y. L., L. P. Sun, X. Zhao, H. Hou and B. F. Li. 2010. Investigation of gelatin polypeptides of jellyfish (Rhopilema esculentum) for their antioxidant activity in vitro. Food Technol. Biotech. 48: 222-228

Zheng, L., M. Zhao, C. Xiao, Q. Zhao and G. Su. 2016. Practical problems when using ABTS assay to assess the radicalscavenging activity of peptides: Importance of controlling reaction $\mathrm{pH}$ and time. Food Chem. 192: 288-294. 